\title{
Australian Journal of

\section{The effect of novel biodegradable films on agronomic performance of zucchini squash grown under open-field and greenhouse conditions}

\author{
Di Mola Ida ${ }^{1}$, Cozzolino Eugenio ${ }^{2}$, Ottaiano Lucia ${ }^{1}$, Duri Luigi Giuseppe ${ }^{1}$, Riccardi Riccardo ${ }^{3}$, Spigno \\ Patrizia $^{3}$, Leone Vincenzo ${ }^{2}$, Mori Mauro ${ }^{1}$ \\ ${ }^{1}$ Department of Agricultural Science University of Naples “Federico II" via Università 100, 80055 Portici Napoli Italy \\ ${ }^{2}$ CREA-Research Centre for Cereal and Industrial Crops, via Torrino 2, 81100 Caserta Italy \\ ${ }^{3}$ ARCA 2010 S.c.a.r.I., via G. Leopardi 18, Teverola Caserta Italy
}

*Corresponding author: Di Mola Ida, ida.dimola@unina.it

\begin{abstract}
The soil mulching is an important agricultural practice for increasing crop productivity and earliness. Mulching can be made with natural or synthetic materials. The common films being used these days are usually made of low density polyethylene (LDPE), but its disposal can represent a serious environmental and economic problem. The biodegradable mulching can overcome these problems. Two experiments were carried out comparing the effects of biodegradable and LDPE mulching films on yield and quality of zucchini (Cucurbita pepo L.) grown in two environments (open-field vs. greenhouse). In both the environments a randomized complete block design was adopted. The treatments composed of no-mulched crop (control), soil covered by 15 microns black biodegradable film (MB15) and soil covered by 50 microns black LDPE film. The results showed that MB15 was able to maintain discrete technical proprieties until the end of cycle, especially in greenhouse, assuring a sufficient heating of soil, similar to LDPE. The soil heating promoted crop development. Furthermore, earliness was increased (84 in greenhouse vs. 99 days in open air) in greenhouse. The early production of zucchini grown on MB15 was similar to the one in LDPE production in greenhouse. The total marketable yield of plants grown on both films was not different but it was lower in open air. The biodegradable film significantly improved fruits quality, with higher values of firmness and total soluble solid than fruits grown on LDPE.
\end{abstract}

Keywords: Cucurbita pepo, fruits quality, mulching, soil temperature, yield.

Introduction

Zucchini (Cucurbita pepo L.) is an important vegetable widely grown under both open-field and greenhouse conditions. It is common in the Mediterranean region, especially in Italy, where about 14300 ha are cultivated (ISTAT, 2017), the $47 \%$ of which in South Italy. In order to satisfy the high demand of this horticultural crop at both national and international markets, zucchini is often grown under greenhouse conditions with high agricultural input (drip-irrigation system, mulching films). The soil mulching is an important agricultural practice for increasing crop productivity by conserving soil humidity and increasing soil temperature (Wang et al., 2011; Malinconico et al., 2008; Espi et al., 2006; Li et al., 2004; Anderson et al., 1995). The increase of root zone temperature can influence several physiological processes such as water and nutrients uptake (IbarraJimenez et al., 2011; Diaz-Perez, 2010; Dodd et al., 2000; Tindall et al., 1990) and improve faster crop development. Furthermore, mulching can significantly reduce the demand for irrigation and improve water use efficiency (Kirnak and Demirtas 2006), and may also help to control harmful insects or pests (Necibi et al. 1992). Black mulching films also allow to suppress weeds (Anzalone et al. 2010; Coolong 2010) and pathogens (Li et al., 2014; Liu et al., 2010), while a large part of pre-harvest costs are due to weed control (Jenni et al. 2004). Therefore, mulching allows to reduce production costs. Mulching can be made with natural or synthetic materials, and also with blends of both. They can vary in thickness, color, texture and lifetime (Kasirajan and Ngouajio, 2012; Maliconico et al., 2008). Currently, the common plastic films that being used are polyethylene, especially low density polyethylene (LDPE), polyvinylchloride, polybutylene or copolymers of ethylene with vinylacetate (Briassoulis, 2007).

Instead, natural mulches can derive from animal and plant materials (Kasirajan and Ngouajio, 2012). The effect of plastic films on soil temperature and crop canopy microclimate depends on their properties in reflection, transmission, and absorption of light (Ham et al., 1993). Waggoner et al. (1960) evaluated microclimatic changes due to various mulches (polyethylene film, straw, paper, and aluminum films) and found that polyethylene (PE) film was the most effective mulching. But the effects of plastic mulches on soil temperature and moisture typically decrease with soil depth, becoming mostly insignificant below $40 \mathrm{~cm}$ 
(Díaz-Hernández and Salmerón, 2012). The low-density polyethylene are inexpensive, easy to apply, durable, thin and available in a range of widths, thicknesses and colors (Lamont 2005). However, the main limit of PE films and other plastic films is their disposal, so that often they are buried or burned (Kyrikou et al. 2007; Ren 2003), while the proper recycle is often difficult and expansive because the mulching films are contaminated with soil and pesticides. The biodegradable films allow overcoming these environmental pollution problems (Tsia et al. 2009). They are composed mostly of polysaccharides such as cellulose and starch, so they may be a promising alternative to retain the advantages and overcome the shortcomings of the conventional PE films (Kijchavengkul et al., 2008). In fact, at the end of their lifetime, biodegradable films can be incorporated directly into the soil or disposed into a composting system and biodegraded by soil microorganisms (Moreno and Moreno, 2008). Maliconico et al. (2008) reported the costs for the buying, removal and disposal of plastic (LDPE) and biodegradable (Mater-bi $15 \mu$ ) films. The total costs are 560 euro per hectare vs 707 euro respectively, but with the biodegradable film with $12 \mu$ thickness the total costs are 566 euro per hectare like as LDPE. Several research experiments under both open-field and greenhouse conditions were carried out to assess the response of several vegetable crops to biodegradable mulching: tomato (Moreno et al., 2009), strawberry (Costa et al., 2014; Bilck et al., 2010), melon (López et al., 2007; Candido et al., 2003) and pepper, eggplant, cantaloupe and sweet corn (Waterer, 2010). However these studies on application of biodegradable films in agriculture are not complete and more scientific researches are needed to understand their effects on the agronomic performance of vegetable species as well as on their endurance respect to weathering. Based on the above considerations two experiments were carried out comparing the effects of biodegradable and LDPE mulching films on yield and quality of zucchini (Cucurbita pepo L.) grown in two environments (open-field vs. greenhouse).

\section{Results}

\section{Air and soil temperature trends in the two different growing conditions}

In greenhouse (Fig 1A) the soil and air temperatures were increased for the whole cycle except in the second and third decade of May. In the first month of trial the air temperature was higher than soil temperatures in all treatments ( 19.1 vs. $17.2^{\circ} \mathrm{C}$, respectively), but this trend was inverted in the last weeks of trial when the air temperature was only higher than control soil temperature. The soil mulching treatments (MB15 and LDPE) showed temperatures in the $0-20 \mathrm{~cm}$ layer higher than the control soil $\left(23.6\right.$ vs. $21.2^{\circ} \mathrm{C}$, on the average of all values of two mulching films vs. control values, respectively). In the hot months (June and July) the differences between the three treatments were more evident. In fact, the soil temperature under biodegradable film was $2^{\circ} \mathrm{C}$ higher than that of LDPE and $7.5^{\circ} \mathrm{C}$ higher than that of control soil on the average. The mulching films had a different behavior under open field conditions (Fig 1B), while the LDPE film determined a soil heating in the first month with temperatures higher than MB15 $\left(+0.7^{\circ} \mathrm{C}\right)$ and the air $\left(+0.8^{\circ} \mathrm{C}\right)$. In the last month of cycle, the soil temperature of MB15 showed intermediate values between the control and the LDPE treatment. By the end of May, the air temperature was higher than the soil temperatures of all treatments. The Growing Degrees Days (GDD) of zucchini were the same in two growing conditions. They were about 955 (Table 1), but the two cycles showed a different length: 84 and 99 days for greenhouse and open air condition, respectively. Considering the two main crop phases (growth and productive phase), the differences between the two environment growing conditions were mainly in the vegetative phase (from transplant to first harvest). The GDDs of this phase were $278^{\circ} \mathrm{C}$ on the average but they were reached 31 and 41 days after transplant for greenhouse and open air condition, respectively.

\section{Yield, biomass dry matter and nitrogen content of plant} organs

The interaction between growing conditions (greenhouse and open-field conditions) and mulching (bare soil-control, LDPE and MB15) was significant for early yield, marketable yield, fruit number per plant, fruit average weight and nitrogen content of stems, leaves and fruits of early yield. In both cultivation conditions the control (not covered soil) showed the lowest values of early yield, corresponding to the sum of the first eight harvests (Fig 2). The mulching films had a different behavior in the two growing conditions. The LDPE reached the highest values $(+38 \%$ vs. the average of all other treatments) in open field conditions. In greenhouse, the biodegradable film showed the highest value with no significant differences with LDPE. The total marketable yield (Table 2) of both mulching films was statistically higher under protected conditions than the corresponding treatments in open field $(+10 \%)$. This productive behavior was mainly due to the statistically higher values of average fruit weight $(+14.8 \%$ respect open air values) and lower degree to the number of fruits per plant. In both samplings, all treatments showed higher nitrogen concentration in fruits than stems and leaves (Table 3). At the eighth harvest, this trend was mainly evident in the three treatments with the higher values of early yield (MB15- greenhouse and LDPE in both conditions). The nitrogen concentration in their fruits, stems and leaves was $5.64 \%, 2.64 \%$ and $1.81 \%$, respectively, versus $4.05 \%, 3.69 \%$ and $2.64 \%$ of all other treatments. Also at the last harvest, in plants of all treatments we observed an higher nitrogen concentration in fruits (about $5.6 \%$ and $4.5 \%$ in greenhouse and open air, respectively). At the end of cycle, under greenhouse condition, the percentage incidence of green leaves of control plants (Fig 3) was higher than that of the other two treatments ( $62.2 \%$ vs $42.6 \%$, respectively) and vice versa for yellow leaves, suggesting that the cycle of control plants showed a delay respect the other treatments. Under open field-conditions (Fig 4), there were not differences between the plants of bare and covered soils in terms of percentage incidence of green leaves. For the control plants it was $45.3 \%$ vs $41.5 \%$ of plants of the two mulching films. 
Table 1. Growing degrees days and corresponding length, expressed as days after transplant (DAT), in greenhouse (Portici) and open air (Acerra).

\begin{tabular}{lcccc}
\hline Crop phases & \multicolumn{2}{c}{ Growing Degrees Days } & \multicolumn{2}{c}{ Length } \\
\hline & \multicolumn{2}{c}{${ }^{\circ}$ C-Day } & DAT & Open air \\
\cline { 2 - 5 } Growth phase & Greenhouse & Open air & Greenhouse & 41 \\
Productive Phase & 281.2 & 275.0 & 31 & 58 \\
All cycle & 669.1 & 683.1 & 53 & 99 \\
\hline
\end{tabular}

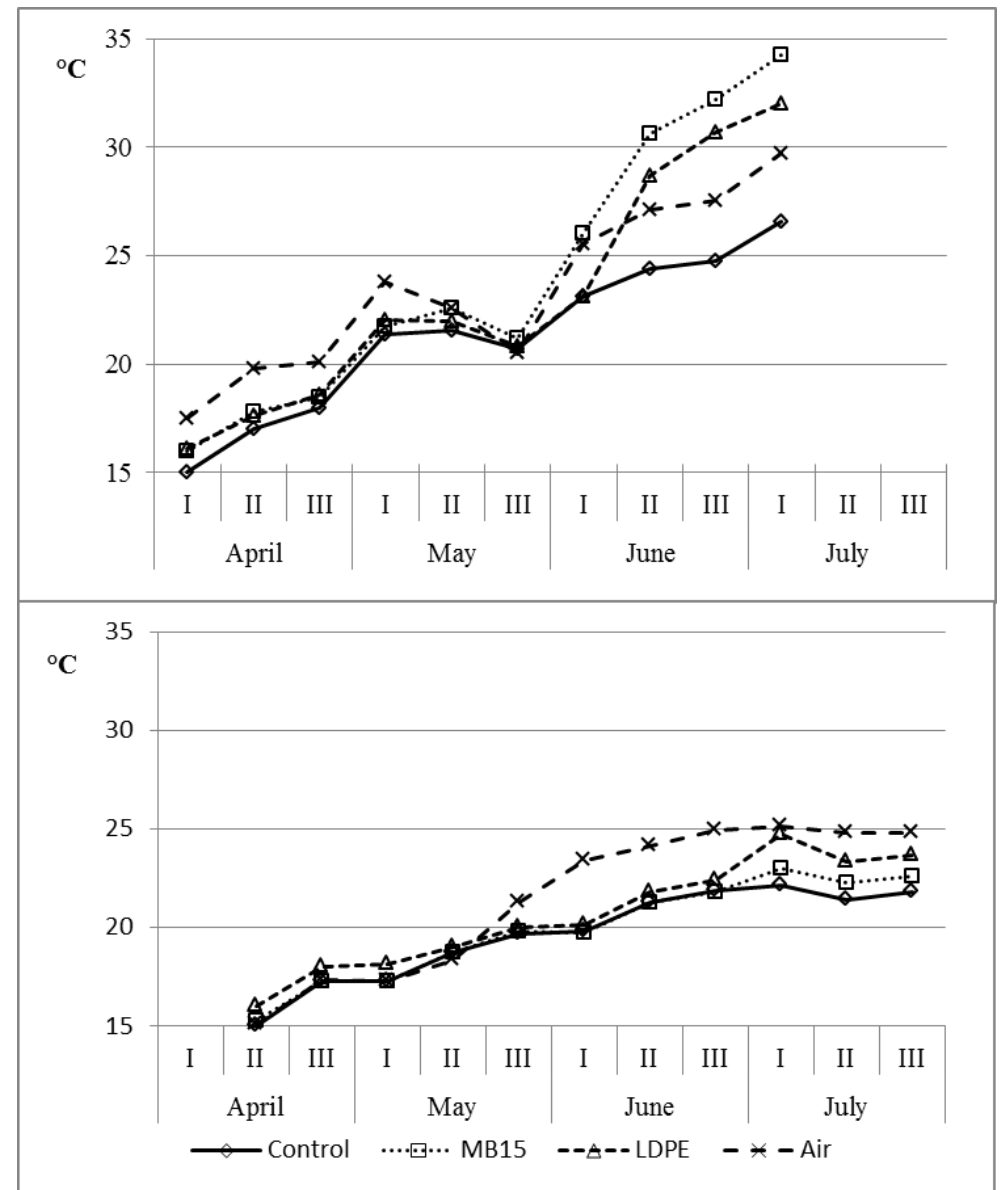

A

B

Fig 1. Trend of average temperature of air and soil treatments in greenhouse (A-Portici) and in open air (B-Acerra).

Table 2. Interaction between growing condition and mulching films on marketable yield, fruit number per plant and fruit average weight.

\begin{tabular}{|c|c|c|c|c|}
\hline Treatments & & Marketable yield & Fruit & \\
\hline & & & $n^{\circ}$ plant $^{-1}$ & gr fruit $^{-1}$ \\
\hline Growing conditions & Mulching & & & \\
\hline \multirow[t]{3}{*}{ Greenhouse } & Control & $34.7 d$ & $30.3 d$ & $114.5 b$ \\
\hline & MB15 & $50.4 a$ & $39.6 b$ & $127.0 a$ \\
\hline & LDPE & $49.8 a$ & $39.2 b$ & $127.1 a$ \\
\hline \multirow[t]{3}{*}{ Open air } & Control & $39.5 c$ & $34.5 c$ & $114.6 b$ \\
\hline & MB15 & $45.8 b$ & $39.2 b$ & $116.9 b$ \\
\hline & LDPE & $45.3 b$ & $44.0 a$ & $104.4 c$ \\
\hline \multicolumn{5}{|l|}{ Significance } \\
\hline Growing conditions (GC) & & NS & $* * *$ & $* * *$ \\
\hline Mulching (M) & & $* * *$ & $* * *$ & $*$ \\
\hline $\mathrm{GC} \times \mathrm{M}$ & & $* * *$ & $* * *$ & $* *$ \\
\hline
\end{tabular}




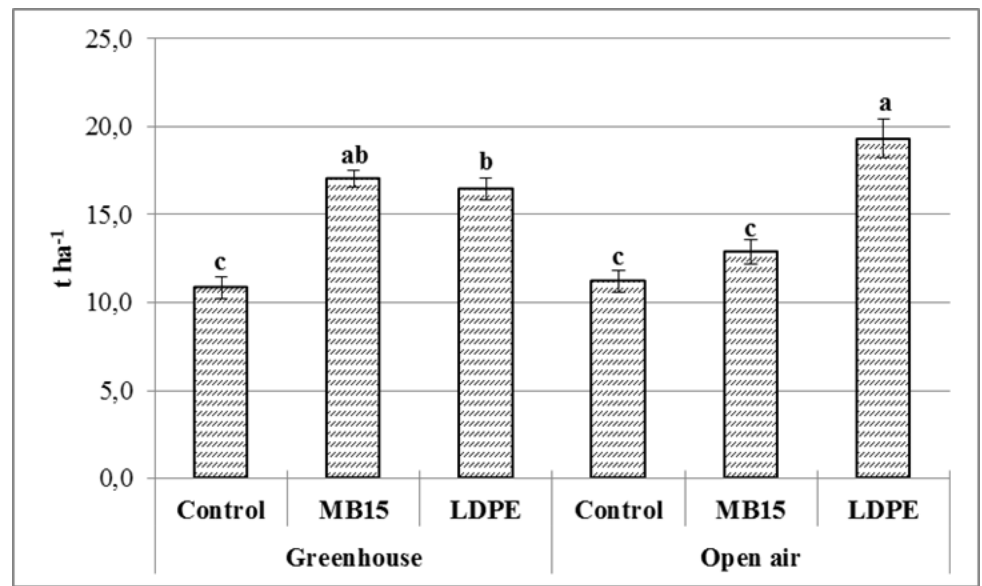

Fig 2. Effect of mulching and growing conditions on early yield (sums of the first 8 harvests) of zucchini squash. The mean values with the same letter do not differ according to the Duncan test $(p<0.05)$.

Table 3. Interaction between cultivation condition and mulching films on total nitrogen content in the different parts of plant at the eight harvest (EH) and final harvest (FH).

\begin{tabular}{|c|c|c|c|c|c|c|c|}
\hline \multirow[t]{3}{*}{ Treatments } & & \multicolumn{6}{|c|}{$N(\% d w)$} \\
\hline & & \multicolumn{2}{|c|}{ Leaves } & \multicolumn{2}{|c|}{ Stems } & \multicolumn{2}{|c|}{ Fruits } \\
\hline & & $E H$ & $\mathrm{FH}$ & $E H$ & $\mathrm{FH}$ & $E H$ & $\mathrm{FH}$ \\
\hline Growing conditions & Mulching & & & & & & \\
\hline \multirow[t]{3}{*}{ Greenhouse } & Control & $2.51 \mathrm{a}$ & 2.46 & $3.67 \mathrm{a}$ & 1.21 & $4.07 \mathrm{~b}$ & 5.80 \\
\hline & MB15 & $1.89 \mathrm{~b}$ & 2.63 & $2.54 \mathrm{~b}$ & 1.44 & $5.13 \mathrm{a}$ & 5.87 \\
\hline & LDPE & $1.78 \mathrm{~b}$ & 2.49 & $2.66 \mathrm{~b}$ & 1.11 & $5.91 \mathrm{a}$ & 5.13 \\
\hline \multirow[t]{3}{*}{ Open air } & Control & $2.65 \mathrm{a}$ & 3.00 & $3.75 \mathrm{a}$ & 2.10 & $3.93 \mathrm{~b}$ & 4.83 \\
\hline & MB15 & $2.77 \mathrm{a}$ & 3.12 & $3.65 \mathrm{a}$ & 2.11 & $4.16 \mathrm{~b}$ & 4.35 \\
\hline & LDPE & $1.75 \mathrm{~b}$ & 3.55 & $2.71 b$ & 2.45 & $5.89 \mathrm{a}$ & 4.27 \\
\hline Greenhouse & & $2.06 \mathrm{~b}$ & $2.53 \mathrm{~b}$ & $2.96 \mathrm{~b}$ & $1.25 \mathrm{~b}$ & $5.04 \mathrm{a}$ & $5.60 \mathrm{a}$ \\
\hline Open air & & $2.39 \mathrm{a}$ & $3.22 \mathrm{a}$ & $3.37 \mathrm{a}$ & $2.22 \mathrm{a}$ & $4.66 \mathrm{~b}$ & $4.48 \mathrm{~b}$ \\
\hline Control & & $2.58 \mathrm{a}$ & 2.73 & $3.71 \mathrm{a}$ & 1.66 & $4.00 \mathrm{~b}$ & 5.32 \\
\hline MB15 & & $2.33 \mathrm{a}$ & 2.88 & $3.10 \mathrm{~b}$ & 1.78 & $4.65 \mathrm{~b}$ & 5.11 \\
\hline LDPE & & $1.77 \mathrm{~b}$ & 3.02 & $2.69 \mathrm{~b}$ & 1.78 & $5.90 \mathrm{a}$ & 4.70 \\
\hline \multicolumn{8}{|l|}{ Significance } \\
\hline Growing conditions (GC) & & $*$ & $* *$ & $* *$ & $* *$ & $*$ & $* *$ \\
\hline Mulching (M) & & $* *$ & NS & $* *$ & NS & $* *$ & NS \\
\hline $\mathrm{GC} \times \mathrm{M}$ & & $* *$ & NS & $* *$ & NS & $* *$ & NS \\
\hline
\end{tabular}

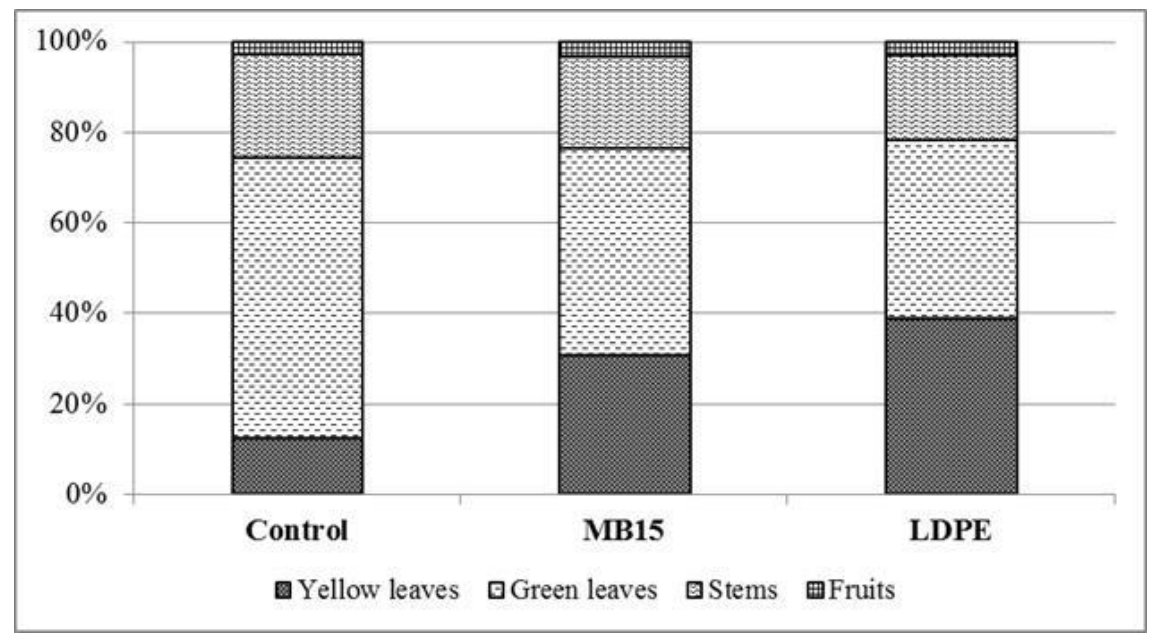

Fig 3. Percentage incidence of different parts of plants on total dry matter at the last harvest: effect of mulching films in greenhouse (Portici) 
Table 4. Main effect of growing condition and mulching films on qualitative parameters of yield.

\begin{tabular}{|c|c|c|c|c|c|}
\hline Treatments & $\mathrm{L}^{*}$ & $a^{*}$ & $\mathrm{~b}^{*}$ & $\begin{array}{l}\text { Firmness } \\
\mathrm{kg} \mathrm{cm}^{-2}\end{array}$ & $\begin{array}{c}\text { Total soluble solids } \\
{ }^{\circ} \text { Brix }\end{array}$ \\
\hline \multicolumn{6}{|l|}{ Mulching } \\
\hline Control & $44.44 b$ & $-15.77 a$ & $23.87 \mathrm{~b}$ & $1.61 b$ & $4.26 b$ \\
\hline MB15 & $50.84 a$ & $-15.82 a$ & $26.38 \mathrm{a}$ & $1.71 a$ & $4.62 a$ \\
\hline LDPE & $45.55 b$ & $-14.24 b$ & $20.93 c$ & $1.51 c$ & $4.34 b$ \\
\hline \multicolumn{6}{|l|}{ Growing conditions } \\
\hline Greenhouse & 45.84 & -14.74 & 23.63 & $1.64 a$ & $4.59 a$ \\
\hline Open air & 48.04 & -15.81 & 23.82 & $1.58 b$ & $4.22 b$ \\
\hline \multicolumn{6}{|l|}{ Significance } \\
\hline Mulching (M) & $* *$ & $*$ & $* *$ & $* * *$ & $* * *$ \\
\hline Growing conditions (GC) & NS & NS & NS & $* *$ & $* * *$ \\
\hline $\mathrm{GC} \times \mathrm{M}$ & NS & NS & NS & NS & NS \\
\hline
\end{tabular}

Different letters within each column indicate significant differences according to Duncan's test $(P \leq 0.05)$

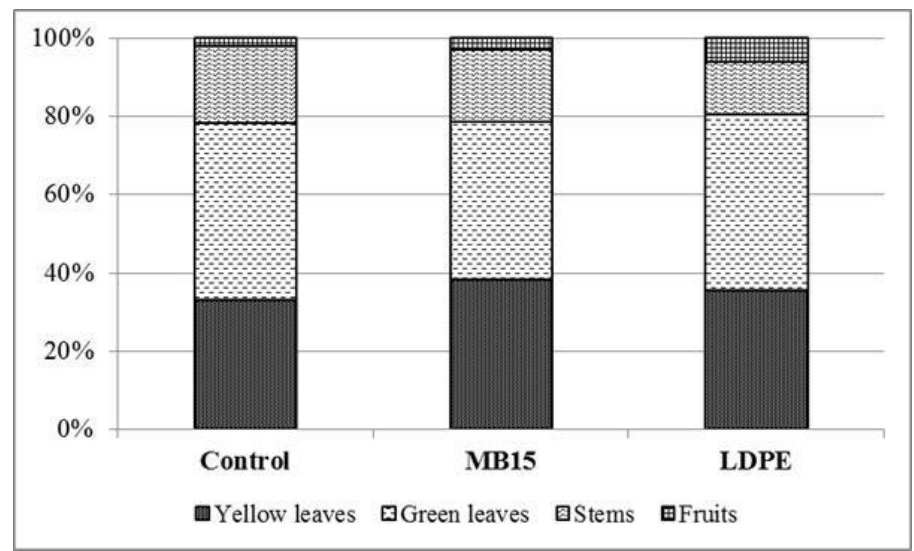

Fig 4. Percentage incidence of different parts of plants on total dry matter at the last harvest: effect of mulching films in open air (Acerra).

Table 5. Degradation parameters of biodegradable film according to the standard scoring made by Novamont technicians, based on visual observation, using a scale with a rate score from 1 to 9 (best conditions).

\begin{tabular}{|c|c|c|c|c|}
\hline Treatments & $\begin{array}{l}\text { Degradation of the } \\
\text { covered film }\end{array}$ & $\begin{array}{l}\text { Degradation of } \\
\text { uncovered film }\end{array}$ & Lesions & Resistance to tearing \\
\hline MB15 Greenhouse & $7.8 \mathrm{NS}$ & $6.4 \mathrm{NS}$ & $7.1 \mathrm{a}$ & $6.2 \mathrm{NS}$ \\
\hline MB15 Open air & $8.0 \mathrm{NS}$ & $6.5 \mathrm{NS}$ & $6.0 \mathrm{~b}$ & $6.3 \mathrm{NS}$ \\
\hline
\end{tabular}

Table 6. Physical and chemical proprieties of greenhouse (Portici) and open air (Acerra) soil.

\begin{tabular}{lccc}
\hline Parameters & & Greenhouse & Open-air \\
\hline Texture & $\%$ & 33.7 & 22.2 \\
$\quad$ - Coarse sand & $\%$ & 41.9 & 39.9 \\
$\quad$ - Fine sand & $\%$ & 16.7 & 22.2 \\
$\quad$ - Silt & $\%$ & 7.7 & 15.6 \\
$\quad$ - Clay & $\%$ & 0.11 & 0.18 \\
$\mathrm{~N}-$ total (Kjeldahl method) & $\mathrm{ppm}$ & 87 & 216 \\
$\mathrm{P}_{2} \mathrm{O}_{5}$ (Olsen method) & $\mathrm{ppm}$ & 1811 & 2173 \\
$\mathrm{~K}_{2} \mathrm{O}$ (Tetraphenylborate method) & $\%$ & 1.7 & 2.9 \\
Organic matter (bichromate method) & & 6.9 & 7.4 \\
$\mathrm{pH}$ & $\mathrm{dS} \mathrm{m}$ & 0.60 & 0.13 \\
Electrical conductivity & & & \\
\hline
\end{tabular}

\section{Fruit quality}

Both growing conditions and mulching films significantly affected the firmness and the total solid soluble contents, whereas the fruit lightness $\left(L^{*}\right)$, the intensities of yellow color (expressed by positive $b^{*}$ values) conditions and the intensities of green color (expressed by negative $a^{*}$ values) on the fruit surface were affected by the mulching films (Table 4). The fruit firmness and total soluble solids content were significantly higher in greenhouse than under openfield conditions: $+4.2 \%$ and $+8.7 \%$, respectively. Instead the 
open field conditions intensified the lightness and yellow color of fruits epidermis (Table 4).

The biodegradable film had a positive effect on lightness, firmness and total soluble solids content of zucchini squash, while the LDPE and control showed no differences, except on the fruit firmness where the LDPE exhibited lower values compared to the control treatment.

\section{Degradation of film}

The degradation of MB15 was evaluated during the cycle, every three weeks. However, in Table 5 we only reported the results observed at end of cycle.

The biodegradable films had a discretely positive behavior in both environmental conditions attributed to the total crop covering of film, since 30 days after transplanting. Only the number of lesions were higher in open air, probably due to the stronger action of weathering.

The degradation points of the covered film were lower than degradation points of the uncovered one both in open air and in greenhouse. Finally, the resistance to hand tearing was similar.

\section{Discussion}

The mulching film had an important role in the crop cultivation because it was able to improve the micro-climate at root zone level, reducing the water loss by evaporation (more uniform moisture content), increasing temperature in the top layer of soil (Emmert, 1957) as well as avoiding the temperature fluctuation in this layer (Moreno and Moreno, 2008). These favorable conditions promote a faster growth and an earlier harvest (Ibarra-Jimenez et al., 2006; Lamont, 2005; Diaz-Perez and Batal, 2002). Moreover, the black mulching films also reduce the growth of weeds and consequently the weeding costs.

Although it is true that the input costs (water, weeding, etc.) can decrease in some cases but at end of lifetime, the mulching films are considered waste and their disposal are usually difficult. In fact, they can be taken to landfill or to incinerator to produce energy or they can be recycled. However, this is often impossible because the films are contaminated with soil; therefore, the recycling process is long and expansive. To overcome these problems, the use of biodegradable films has been increased significantly in the last two decades (Malinconico et al., 2002). In fact, the advantage of these films is the possibility to be disposed directly in the soil or in composting plants like a normal organic waste (Kapanen et al., 2008).

Several studies were carried out about the use of biodegradable films on some horticultural commodities (Costa et al., 2014; Bilck et al., 2010; Moreno et al., 2009; López et al., 2007; Candido et al., 2003). However, it is necessary to verify if biodegradable films can be a sustainable alternative to conventional LDPE, assuring the same agronomic and technical performance of plastic films on different crops and in different environmental conditions, which can affect the film degradation.

In the present study, we found that mulching, both traditional and biodegradable, heated the $0-20 \mathrm{~cm}$ top soil. This was more evident in greenhouse. The deterioration of the mechanical properties of biodegradable film seemed to affect only the soil temperatures, without interfering with plant growth and production, also because it started at the end of May (data not shown).

In fact the soil heating due to mulching, promoted faster crop development, as demonstrated by higher percentage incidence of yellow leaves of mulching treatments respect to control plants at the harvest. However, it was more evident in greenhouse, where micro-climate conditions (such as high air temperature) increased crop growth rate.

In fact, the length of two cycles was different: 84 vs. 99 days for greenhouse and open air plants, respectively, but the Growing Degrees Days (GDD) were the same (about 955).

The effect of greenhouse microclimate was evident also for early yield that was the same for the two mulching films in greenhouse, while in open air the biodegradable film was not different from control, probably because the LDPE reached higher temperatures in the first month of trial.

The different development and productive behavior of plants under the two different growth conditions were also confirmed by the different translocation of nitrogen in the plant parts. In fact, at the eight harvest, the plants grown on mulching films under greenhouse conditions had less nitrogen concentration of stems and leaves than those grown in open air, while the $\mathrm{N}$ content of fruits showed an opposite trend.

This behavior justified the higher early yield of plants grown on both mulching films in greenhouse conditions. Just like the early yield, even the total marketable yield was higher in greenhouse plants grown on mulching films than in open air plants (about $+10 \%$ ), attributed to more favorable climate conditions. In particular, these mainly produced an increase of fruit weight and secondly the number of fruits per plant, 36.4 and 40.4 in greenhouse in open air, respectively. It is possible that the high temperature in greenhouse caused a problematic pollination of flowers, so the fruits number per plant was lower but they could develop more, according to Mori et al. (2011) in snap bean.

In this study, the organoleptic quality of zucchini squash, expressed as total soluble solids content, improves when the plants grown on biodegradable mulching films, as well as the firmness and the brightness of fruits.

The firmness and total soluble solids content did not exhibited any significant differences between LDPE and biodegradable film for other crops (tomato and melon) (Filippi et al., 2011; Moreno et al., 2009; Moreno et al., 2008). Rouphael et al. (2010, 2012) observed these phenomena for zucchini and related them to the water stress in fruits without affecting synthesis and accumulation of organic solutes.

\section{Materials and methods}

\section{Treatments, experimental design and growth conditions}

The trial was carried out in two contrasting environments:

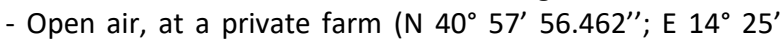
50.213"; 27 m a.s.I.) of the cooperative ARCA 2010 in Acerra (Naples);

- Greenhouse, at the experimental field Gussone Park of Department of Agriculture (N 40 48.' 49.352"; E 14 20' 40.073"; 70 m a.s.I.) in Portici (Naples). 
At the begining of cycle, the soil samplings, at $0-30 \mathrm{~cm}$ deep, were made for determining physical and chemical proprieties. The greenhouse soil was loamy-sand with neutral $\mathrm{pH}$, high content of potassium and phosphorus and good content of total nitrogen and organic matter. The open air soil was sandy-loam with $\mathrm{pH} 7.4$ and high content of potassium, phosphorus, nitrogen and very high presence of organic matter. The physical and chemical proprieties of both soils are reported in Table 6 .

In both environments (greenhouse and open-field), a randomized complete block design was adopted: not covered soil (control); soil covered by 15 microns black biodegradable film (MB15) and soil covered by 50 microns black low density polyethylene (LDPE).

The black biodegradable film (MB15) is a starch-based raw material, known with the trade name Mater-Bi, made of destructured starch treated with biodegradable polyesters by Novamont company (Novara, Italy) (Bastioli, 1998). Polyethylene plastic is made of polyethylene resin, which is in the form of pellets. The pellets are heated and processed into bendable sheets of plastic film. It has easy processibility, excellent chemical resistance, high durability and flexibility (Kasirajan and Ngouajio, 2012).Three replicates per treatment were adopted in both experiments, amounting to a total of 9 experimental plots (two rows each) with 12 plants each ( $n=108$ plants). The films were manually placed in the last decade of March and in the first decade of April in the greenhouse and open air, respectively. The transplants, at the two-true-leaf stage, were made on March 27 in greenhouse and April 8 in open air with a plant density of 1.1 plants per square meter. The tested cultivar was "Altea", a Syngenta hybrid. Their fruits are light green and mottled. They are harvested with flowers at a length of $20-22 \mathrm{~cm}$. Harversts were made every 2 days as following: in open air the harvests, from 19 May to 16 July, for a total of 24 harvests; in greenhouse from 27 April to 19 June, for a total of 23 harvests. The crop was managed following the cultural techniques commonly adopted by Italian farmers. The nitrogen was given at dose of $90 \mathrm{~kg}$ per hectare with 10 fertirrigations with ammonium sulphate (20\%). In open air, the water requirements were totally satisfied by rainfall (463 $\mathrm{mm}$ in the whole cycle). In greenhouse, they were replaced by irrigations, where the equivalent of $4300 \mathrm{~m}^{3}$ per hectare was given.

During the cycle, the temperature of soil was continuously monitored in the layer $0-20 \mathrm{~cm}$ with probes (Vantage Pro2, Davis Instruments). The air temperatures were also measured and they were used for calculating the Growing Degrees Day (GDD) according to formula:

$\sum \frac{(\operatorname{Tmax}+T \min )}{2}-T$ Base

Where; the $T_{\max }$ is the daily maximum temperature; $T_{\min }$ is the daily minimum temperature and $T_{\text {base }}$ is the threshold or base temperature, below which little growth occurs. It varies with plant species and it is $10^{\circ} \mathrm{C}$ for zucchini.

\section{Yield measurements}

At each harvest the number of fruits per plants and the fresh weight of marketable fruits were collected on all plants.
Zucchini fruits were harvested when they reached marketable size. In the last harvest, five representative fruits per replicate were analyzed for fruit quality parameters.

According to the Commission Internationale de L'Eclairage $(\mathrm{CIE})$, the color space parameters $\left(\mathrm{L}^{*}\right.$, lightness, -a*, greenness and $\mathbf{+ b}^{*}$, yellowness) were measured at the center of the external fruit surface using a Minolta CR-300 Chroma Meter (Minolta Camera Co. Ltd., Japan). The measuring aperture diameter was $8 \mathrm{~mm}$, and the Chroma Meter was calibrated with the Minolta standard white plate before sampling the zucchini fruits.

The total soluble solids (TSS) content was measured using an Atago N1 refractometer (Japan) and the firmness measured with a Penetrometer BCE with $8 \mathrm{~mm}$ probe.

At the eighth and final harvest, the above-biomass were sampled and separated into stems, leaves and fruits. All plant parts were dried in a forced-air oven at $70^{\circ} \mathrm{C}$ for dried biomass and nitrogen content determination. The percentage incidence of each plant part was calculated by dividing its dry weight by the total dry weight at the last harvest.

The dried plant tissues (stems, leaves and fruits) were finely ground in a mill (IKA, MF10.1, Germany), sieved at 0.5-mm and, then, used for the analysis of nitrogen. Total $\mathrm{N}$ concentration was determined after mineralization with sulfuric acid $\left(\mathrm{H}_{2} \mathrm{SO}_{4}, 96 \%\right)$ in the presence of potassium sulfate $\left(\mathrm{K}_{2} \mathrm{SO}_{4}\right)$ and a low concentration of copper $(\mathrm{Cu})$ according to the Kjeldahl method (Bremner 1965).

\section{Biodegradable film evaluation}

At the end of cycle, the endurance of biodegradable film to atmospheric agents (precipitation, wind, etc.) was evaluated using the standard scoring made by Novamont technicians. It is based on visual observation and uses a scale with a rate score from 1 to 9 (best conditions), evaluating following parameters: degradation of the covered and uncovered film; lesions and resistance to tearing (Filippi et al., 2011).

\section{Statistical analysis of data}

All experimental data were subjected to analysis of variance (ANOVA) using SPSS version 22.0 (SPSS Inc., USA). Within each measured parameter, means were separated by Duncan's multiple-range test at $P \leq 0.05$. Data of early yield are presented as mean values of three replicates with relative standard errors.

\section{Conclusion}

The biodegradable film was able to maintain discrete technical proprieties until the end of cycle, especially in greenhouse, assuring a sufficient heating of soil, similar to LDPE. The effect of higher soil temperature promoted faster crop development. For the same reason in greenhouse the zucchini cycle was shorter than in open air: 84 vs. 99 days, but both cycles had the same GDD $\left(955^{\circ} \mathrm{C}\right.$-Day).

The early production of zucchini grown on MB15 was similar to the one of LDPE in greenhouse. The total marketable yield of plants grown on both films was not different under both growing conditions. 
Finally, the main effect of biodegradable film was on quality of fruits, which showed a higher firmness and total soluble solid than fruits of plants grown on LDPE. In conclusion, biodegradable film under Mediterranean conditions as those reported in our experiments could be considered a sustainable alternative to the use of traditional plastic film, especially in protected conditions.

\section{Acknowledgements}

We express our thanks to Roberto Maiello and Dr. Sabrina Nocerino for their technical assistance in the laboratory.

\section{References}

Anderson DF, Garisto MA, Bourrut JC, Schonbeck MW, Jaye R, Wurzberger A, De Gregorio R (1995) Evaluation of a paper mulch made from recycled materials as an alternative to plastic film mulch for vegetables. J Sustain Agr. 7: 39-61.

Anzalone A, Cirujeda A, Aibar J, Pardo G, Zaragoza C (2010) Effect of biodegradable mulch materials on weed control in processing tomatoes. Weed Technol. 24(3): 369-377.

Bastioli C (1998) Properties and applications of Mater-Bi starch-based materials. Polym Degrad Stabil. 59(1-3): 263272.

Bilck AP, Grossmann MV, Yamashita F (2010) Biodegradable mulch films for strawberry production. Polym Test. 29(4): 471-476.

Bremner JM (1965) Total nitrogen. In: Black CA, Evans DD, White IL, Ensminger LE, Clark FE (eds) Methods of soil analysis no. 9, part 2. Madison, WI, 1149-1178.

Briassoulis D (2007) Analysis of the mechanical and degradation performances of optimised agricultural biodegradable films. Polym Degrad Stabil. 92: 1115-1132.

Candido V, Miccolis V, Gatta G, Margiotta S, Manera C (2003) Innovative films for melon mulching in protected cultivation. Acta Hortic. 614: 379-386.

Coolong T (2010) Performance of paper mulches using a mechanical plastic layer and water wheel transplanter for the production of summer squash. Horttechnology. 20(2): 319-324.

Costa R, Saraiva A, Carvalho L, Duarte E (2014) The use of biodegradable mulch films on strawberry crop in Portugal. Sci Hortic-Amsterdam. 173: 65-70.

Díaz-Hernández JL, Salmerón T (2012) Effects of a plastic cover on soil moisture change in a Mediterranean climatic regime. Soil Use Manage. 28: 596-605.

Diaz-Perez JC, Batal KD (2002) Colored plastic film mulches affect tomato growth and yield via changes in root-zone temperatures. J Am Soc Hortic Sci. 127 (1): 127-136.

Diaz-Perez JC (2010) Bell pepper (Capsicum annum L.) grown on plastic film mulches: Effects on crop microenvironment, physiological attributes, and fruit yield. Hortic Sci 45 : 1196-2004.

Dodd IC, He J, Turnbull CGN, Lee SK, Critchley C (2000) The influence of supraoptimal root-zone temperatures on growth and stomatal conductance in Capsicum annuum L.. J Exp Bot 51: 239-248.

Emmert EM (1957) Black polyethylene for mulching vegetables. P Am Soc Hortic Sci. 69: 464-467.
Espi E, Salmeron A, Fontecha A, Garcla Y, Real Al (2006) Plastic films for agricultural applications. J Plast Film Sheet. 22: 85-102.

Filippi F, Magnani G, Guerrini S, Ranghino F (2011) Agronomic evaluation of green biodegradable mulch on melon. Ital J Agron. 6 (2): 111-116.

Ham JM, Kluitenberg GJ, Lamont WJ (1993) Optical properties of plastic mulches affect the field temperature regime. J Am Soc Hortic Sci. 118: 188-193.

Ibarra-Jimenez L, Quezada-Martin R, Cedeno-Rubalcava B, Rio AJD, de la Rosalbarra M (2006) Watermelon response to plastic mulch and row covers. Eur J Hortic Sci. 71: 262266.

Ibarra-Jimenez L, Lira-Saldivar H, Valdez-Aguilar LA, Lozanodel Rio J (2011) Colored plastic mulches affect soil temperature and tuber production of potato. Acta Agr Scand B-S P 61: 365-371.

ISTAT (2017) Tavola C13. Superficie (ettari) e produzione (quintali): popone o melone, zucchina, funghi di coltivazione. http://agri.istat.it/

Jenni S, Brault D, Stewart KA (2004) Degradable mulch as an alternative for weed control in lettuce produced on organic soils. Acta Hortic. 638: 111-118.

Kapanen A, Schettini E, Vox G, Itavaara I (2008) Performance and environmental impact of biodegradable films in agriculture: a field study on protected cultivation. J Polym Environ. 16: 109-122.

Kasirajan S, Ngouajio M (2012) Polyethylene and biodegradable mulches for agricultural applications: a review. Agron Sustain Dev. 32: 501 - 529.

Kijchavengkul T, Auras R, Rubino M, Ngouajio M, Fernandez RT (2008) Assessment of aliphatic-aromatic copolyester biodegradable mulch films. Part I: Field study. Chemosphere. 71: 942-953.

Kirnak H, Demirtas MN (2006) Effects of different irrigation regimes and mulches on yield and macronutrition levels of drip-irrigated cucumber under open field conditions. J Plant Nutr. 29: 1675-1690.

Kyrikou I, Briassoulis D (2007) Biodegradation of agricultural plastic films: a critical review. J Polym Environ. 15(2): 125150.

Lamont WJ (2005) Plastics: Modifying, the microclimate for the production of vegetable crops. Horttechnology. 15(3): 477-481.

Li FM, Song QH, Jjemba PK, Shi YCh (2004) Dynamics of soil microbial biomass $C$ and soil fertility in cropland mulched with plastic film in a semiarid agro-ecosystem. Soil Biol Biochem. 36: 1893-1902.

Li C, Moore-Kucera J, Miles C, Leonas K, Lee J, Corbin A, Inglis D (2014) Degradation of potentially biodegradable plastic mulch films at three diverse us locations. Agroecol Sust Food. 38: 861-889.

Liu M, Huang Z, Yang YJ (2010) Analysis of Biodegradability of Three Biodegradable Mulching Films. J Polym Environ. 18: $148-154$

Lopez J, Gonzalez A, Fernandez JA, Banon S (2007) Behaviour of biodegradable films used for mulching in melon cultivation. In: Hanafi A, Schnitzler WH (eds) Proc. VIII IS on protected cultivation in mild winter climates. Acta Hortic. 747:125-130.

Malinconico M, Immirzi B, Massenti S, La Mantia FP, Mormile P, Petti L (2002) Blends of polyvinylalcohol and 
functionalized polycaprolactone. A study of the melt extrusion and post-cure of films suitable for protected cultivation. J Mater Sci. 37: 4973-4978.

Malinconico M, Immirzi B, Santagata G, Schettini E, Vox G, Scarascia Mugnozza G (2008) Chapter 3: an overview on innovative biodegradable materials for agricultural applications. In: Moeller H.W. (Ed.), Progress in polymer degradation and stability research. Nova Science Publishers, New York, 69-114.

Moreno MM, Moreno A (2008) Effect of different biodegradable and polyethylene mulches on soil properties and production in a tomato crop. Sci HorticAmsterdam. 116: 256-263.

Moreno MM, Moreno A, Mancebo I (2009) Comparison of different mulch materials in a tomato (Solanum lycopersicum L.) crop. Span J Agric Res. 7(2): 454-464.

Mori M, Di Mola I, Quaglietta Chiarandà F (2011) Salt stress and transplant time in snap bean: growth and productive behaviour. Int J Plant Prod. 5(1): 49-64.

Necibi S, Barrett BA, Johnso JW (1992) Effects of a black plastic mulch on the soil and plant dispersal of cucumber beetles, Acalymma vittatum (F.) and Diabrotica undecimpunctata howardi Barber (Coleoptera: Chrysomelidae), on melons. J Agr Entomol. 9(2): 129-135.

Ren X (2003) Biodegradable plastics: a solution or a challenge? J Clean Prod. 11: 27-40.
Rouphael Y, Schwarz D, Krumbein A, Colla G (2010) Impact of grafting on product quality of fruit vegetables. Sci HorticAmsterdam. 127: 172-179.

Rouphael Y, Cardarelli M, Bassal A, Leonardi C, Giuffrida F, Colla $G$ (2012) Vegetable quality as affected by genetic: agronomic and environmental factors. I Food Agric Environ. 10: 680-688.

Tindall JA, Mills HA, Radcliffe DE (1990) The effect of root zone temperature on nutrient uptake of tomato. J Plant Nut. 13: 939-956.

Tsia HY, Tsen WC, Shu YC, Chuang FS, Chen CC (2009) Compatibility and characteristics of poly (butylene succinate) and propylene-coethylene copolymer blend. Polym Test. 28: 875-885.

Waggoner PE, Miller PM, De Roo HC (1960) Plastic mulching: principles and benefits. Conn AES Bull. 634 .

Wang FX, Wu XX, Shock CC, Chu LY, Gu XX, Xue X (2011) Effects of drip irrigation regimes on potato tuber yield and quality under plastic mulch in arid Northwestern China. Field Crop Res. 122: 78-84.

Waterer D (2010) Evaluation of biodegradable mulches for production of warm-season vegetable crops. Can J Plant Sci. 90(5): 737-743. 